\title{
Переклади текстів Святого Письма в барокових проповідях
}

\author{
ОКСАНА ЗЕЛІНСЬКА \\ Кафедра української мови та методики ії навчання, Уманський державний педагогічний \\ університет імені Павла Тичини, кім. 304, вул. Садова, 28, UA-20300 Умань \\ E-mail: zelinska67@ukr.net
}

(Received: 9 January 2017; accepted: 15 March 2017)

\begin{abstract}
Some peculiarities of the translation of Holy Scripture fragments in the texts of baroque sermons are discussed in the paper. The author analyzes the features of the national language testified in the translations, and concludes that the preachers studied gospel stories creatively, made them more stylistically expressive, which can be explained by the specificity of homiletic work.
\end{abstract}

Keywords: Ukrainian, 17th century, baroque, sermon, Holy Scripture, spoken language

Барокова проповідь стала одним із жанрів писемності, у межах якого продовжувала утверджуватись ідея про здатність української мови виконувати релігійні функції й бути мовою Святого Письма. Підсумовуючи досвід багатьох поколінь, В. Німчук стверджує: «Якою б генетично близькою не була запозичена мова, найглибше моління людина звершує тоді, коли користується рідною мовою» (НІмчук 2013: 10).

Як відомо, жива мова здавна почала проникати в різноманітні релігійні твори. Народнорозмовні риси знаходять відбиття в конфесійних пам'ятках писемності Київської Русі XI-XII ст., включаючи й канонічні, серед яких досліджено тексти Євсевієвого Євангелія (1283р.), Добрилового Євангелія (1164 р.) (НІмчук 2001а, Осінчук 2012). Торкаючись проблем мови української церкви, Л. Полюга висловив суголосну думку з І. Огієнком, який доводив, що українська літературна мова бере початок з княжої доби, коли користувалися церковнослов'янською писемною мовою, тексти якої читалися з українською вимовою, а згодом до цих текстів при переписуванні книг в Україні підсвідомо вставлялися українські слова або свідомо на полях чи в тексті внутрішньорядкові або покрайні глоси. Українська вимова церковних текстів, український наголос, використання української лексики, на думку I. Огієнка, фіксувалися вже в перших церковних пам'ятках України-Русі (ПолюгА 2004: 241). Проте мовознавці визнають, що відхилення від норм церковнослов'янської мови в ранніх пам'ятках було ще несвідомим. Пам'ятки наступних століть засвідчують активізацію процесів проникнення живої мови в релігійні тексти. 3 другої половини XV століття веде початок «літературне опрацювання старослов'янських текстів із свідомим насиченням їх фонетичними, 
морфологічними, синтаксичними та лексичними особливостями живої народної мови, з прагненням зробити ці тексти доступними і зрозумілими для простого люду при читанні й слуханні церковних книг» (Гринчишин 1995: 251). До таких належить Четья Мінея 1489 р., яку називали «праматір'ю» перекладів (СРмоленко 1989: 59), Крехівський Апостол XVI століття (Огєєнко 1930). Ці твори в різних лінгвістичних аспектах вивчали і вивчають багато істориків мови (О. Горбач, Г. Воронич, В. Німчук, І. Огієнко, Ю. Осінчук, Л. Полюга, К. Симонова, I. Чепіга). До XVI ст. переробки не поширювалися на книги безпосередньо Святого Письма і богослужбові книги. Як зауважила I. Чепіга, наступ книжної української мови на церковнослов'янську в конфесійному жанрі відбувався поступово і дуже обережно, що було зумовлено як високим авторитетом церковнослов'янської мови, так і побоюванням конфесійно небезпечних перекручень у процесі перекладу (Чвпіг 1995: 279).

Принципово якісним проривом живої мови в релігійну сферу стали переклади канонічних текстів. Як відомо, ідея перекладу текстів Святого Письма зародилася ще у XIV-XV ст. і поширилася по всій Європі, згодом вона була підтримана реформаторським рухом, який через Польщу дійшов до України. Церковна проповідь і Святе Письмо рідною мовою - одна з основних вимог протестантизму, який передбачав засвоєння слова Божого розумом (ГРинчишин 1995: 251, ЧЕпІгА 2001: 15). В Україні найбільш знаними перекладами канонічних книг є Пересопницьке Свангеліє, Волинське Євангеліє та ін. На роль перекладів Святого Письма для розвитку мови вказав В. Німчук: «Христове вчення, писемно засвідчене Його апостолами, майже 2000 років перекладають різними мовами теологи і не теологи, збагачуючи мови світу лексичними, семантичними та фразеологічними засобами» (НІмчук 2001b: 12) i до наших днів «триває прагнення якнайточніше передати Христові слова» (НІмчук 2013: 11). Л. Гнатюк стверджує, що ідея цінності рідної мови була проявом специфіки мовної свідомості тогочасного українського суспільства і співзвучною з процесами розвитку мовної свідомості в Свропі загалом (ГнАтюк 2010: 78-79). Водночас дослідники акцентують, що переклади канонічних творів не могли кардинально вплинути на розвиток літературної мови, бо були рукописними, але їх поява виразно свідчить про інтенсивний процес творення української мови на новій основі, віддаляючись від загальних традицій давньоруської писемності й звертаючись до національних джерел, до народнорозмовного субстрату (Толстой 1963: 242). Важливо, що перекладацька діяльність українських книжників виявилася не тільки на матеріалі цілісних текстів, а й у перекладах частин, які цитували у творах різних жанрів. Велика робота з перекладу фрагментів канонічних творів засвідчена у збірниках традиційних проповідей, особливо Учительних Євангеліях, що підвищувало суспільний статус і престиж української мови (ДоБосевич 2007). Однією з найбільш відомих пам'яток релігійної літератури, мова якої наближена до народної, є Нягівські повчання, вперше опубліковані А. Петровим у 1914 р. (ПЕтров 1914, див. ЗолтАн 2006: Х, Дидик-МЕуш 2008). Чимало цитат із пам'яток від XVI до XVIII ст., що містять народні переклади біблійних 
текстів, зібрав та опублікував Шандор Бонкало у підручнику, що вийшов під псевдонімом О. Рахівський. Окремі цитати автор виокремлює під заголовком «Приклады переводу свят. писанія изъ Няговського Учительного евангелия» (РАХІвський 1919: 23-24).

Укладачі Учительних Євангелій перекладали уривки з євангельського тексту, що передував власне проповіді й був покладений у іiі основу. I. Огієнко переконував, що, зібравши розпорошені в текстах Учительних Свангелій цитати, можна було б отримати кілька варіантів українського перекладу значних частин Біблії вже наприкінці XVI століття (ОгІєнко 1930: 121, ЧуБА 2000: 453). Саме на вагомості варіантів перекладів акцентує I. Чепіга: «Для вивчення мови певної епохи перекладні тексти дають матеріал такого значення, який не може бути почерпнутий 3 пам'яток оригінальних. 3 одного боку, ці тексти являють собою пам'ятки абсолютно однакові за змістом, ті самі думки передано в однаковій послідовності. 3 іншого боку, перекладалися й переписувалися такі тексти різними людьми, що походили 3 різних територій, по-різному володіли літературною, відбивали різні мовні тенденції й смаки й різні літературні манери... Таким чином, перекладні конфесійні тексти є ніби результатом заданого епохою змагання, що показують різні варіанти вирішення тих самих завдань» і додає, що «навіть той самий перекладач може давати варіанти перекладу, не кажучи вже про переклад різних пам'яток» (ЧепггА 1995: 281, ЧЕпІгА 2001: 25-26). Думку про важливість варіантів перекладу поділяє сучасна дослідниця Учительних Євангелій Г. Чуба, покликаючись і на I. Франка, і на Ю. Тиховського, який зазначав, що збережені списки і друковані видання Учительних Євангелій є не лише копіями, а щораз новими переробками і перекладами, а також на польського дослідника Я. Янува, який констатував, що за кількістю та різноманітністю виявів живої народної мови тексти Учительних Свангелій перевищували інші пам'ятки того часу і навіть Пересопницьке Євангеліс (ЧуьА 2011: 18-19). У. Добосевич слушно зауважує, що через посередництво проповідницького жанру відбувався процес наближення церкви до всіх верств народу, і це посилило, за висловом М. Грушевського, християнізацію української народної маси, опанування церковними мотивами народного життя, релігійного світогляду, обряду і творчості (ДоБосевич 2013: 61).

Як показує досліджуваний матеріал, творці барокових проповідей продовжували ці традиції, включаючи у свої казання переклади біблійних текстів. Перекладам Святого Письма у творах І. Галятовського - «доброго проповідника й вибагливого стиліста» - присвятив спеціальну розвідку В. Сімович, який писав: «Цей письменник порозсипував у своїх творах то довші, чи коротші вривки то поодинокі речення з перекладених ним таки місць із святого письма, Старого та Нового завіту; його проповіді містять у собі силу цитат із Біблії, що він їх частенько зараз таки й передає мовою інтелігентних українських шарів XVII ст. Тим то такі „спроби“ знайдуться і в Ставровецького, і в Радивіловського, і в інших письменників - тільки ж досі на це не звернуто належної уваги... Переклади у Галятовського траплялись дослівні, 
але часто цілком вільні», бо це, стверджував дослідник, «було зумовлено практикою проповідника, для якого важливіше було передати думку» (Сімович 1930: 51). Характеризуючи стиль І. Галятовського, В. Сімович зазначав: «...слова пливуть гладко, в вислові видно навіть деяку елеганцію... Галятовський добирає слів, щоб образи не виходили бліді» (СІмович 1930: 60). Учений спостеріг, що до одного старослов'янського вислову проповідник добирає двоє, а то й більше. Але найголовніше, що, перекладаючи Святе Письмо, автор використовує народну лексику і фразеологію, змінює іменні конструкції на прикметникові звороти, у прийменникових зворотах старослов'янські прийменники замінює іншими, такими, що й досі вживаються в українській мові (СІмович 1930: 70).

Досліджувані тексти презентують численні зразки перекладів фрагментів зі Святого Письма: це насамперед епіграфи до проповідей, які, повторюючись у розгортанні викладу змісту, постають у різних варіантах. Промовистим у розгляданому аспекті є використання епіграфа у проповіді П. Могили «Хрест Спасителя і кожної людини». Автор подав кілька варіантів перекладу тієї самої цитати. На початку казання він наводить їі в церковнослов'янському мовному оформленні й паспортизує:

Рече Гд̈ь: Иже хощет по мнъ ити, да $\omega($ т)вержеса себе, и възметъ Крестъ свой и по мнъ грАдетъ. Ма(р): Гла(в): й. Зачало, лӟ (Мог., Хрест 271).

Епіграф водночас слугує і темою проповіді, яка складається з двох частин, а тому П. Могила наводить цей же вислів ще кілька разів: у вступі до проповіді, на початку першої і другої частини і фрагментарно у викладі змісту, але вже в перекладі книжною українською мовою. Зауважимо, що ці переклади різняться. В усіх випадках до слова хощет автор добирає фонетичний відповідник хочете; лексичний церковнослов'янізм грясти, який обмежено вживався в українських пам'ятках досліджуваного періоду (СУМ 16-17, 7: 110), замінено лексемою іти, отвержеся - лексемою запритися «відмовитися, відректися», властивою церковнослов'янській мові та яка набула активного поширення в текстах різних жанрів (СУМ 16-17, 10: 167). Виявлено кілька варіантів перекладу словосполучення по мнъ грАдетъ. В одному випадку його передано відповідником зі специфічно українською формою дієслова в наказовому способі з часткою нехай - за мною нехай идеть, а в інших словосполученням посльдуетъ мнъ, пор.:

1. Кто хочетъ за мною ити, нехайса себе самого запритъ, и нехай възметъ Кресть свой и посльдуеть мнђ (Мог., Хрест 272).

2. Кто хочетъ за мною ити, нехайса самого себе запритъ, и нехай възметь Кресть свой и посльдуеть мнъ (Мог., Хрест 272, 273).

3. Кто хочетъ за мною ити, нехайса заприть самого себе, и нехай възметъ Кр(с)ть свой, а за мною нехай идетъ (Мог., Хрест 280).

Зауважимо, що наведені 1 і 2 цитати різняться ще й порядком слів; крім того, перекладаючи, П. Могила стилістично увиразнює їх за допомогою повтору 
слова нехай, в останньому випадку - три рази. Порівняймо 3 перекладом у Пересопницькому Свангелії:

Ссли же хочеть кто за мною поити, нехаи са заприть себе и възметь кр(с)ть свои и за мною идеть (ПЄ 222).

Розкриваючи тему проповіді, П. Могила коментує євангельський вислів, розбиваючи його на смислові фрагменти, і знову подає варіанти з різними прийменниково-займенниковими конструкціями: по мнъ - всльд мене - за мною:

Мови(т) бовђм: Кто хочетъ за мною ити (Мог., Хрест 281).

А што мови(т), по мнъ ити, альбо всльд мене нехай идетъ (Мог., Хрест 282).

П. Могила тлумачить зміст словосполучення $c$ А заприть самого себе і добирає ще два синоніми до дієслова:

Нехайса заприть самого себе, тоесть, нехай всю свою власную волю и вынищить (Мог., Хрест 282).

Підбір лексичних відповідників відбувався не тільки при дослівному перекладі цитати, а й тоді, коли вона була відправним пунктом розгортання проповіді всередині тексту, коли проповідник розмірковував над ії змістом, висловлював суголосну цитаті думку чи розвивав їі, замінюючи ключові лексеми 3 цитати синонімами, що спостерігаємо в різних авторів. Наприклад, слову сохранити, вжитому в цитаті, в авторському тексті відповідає дієслово стерегти:

Зачы(м) встидаймосА агг̃ла, сторожа своего... жебы смо грђхюмъ своимъ себе не $\omega($ т)гнали агг̃ла, которыи стережет(ъ) насъ на кождомъ мъстцу ведлугъ ұалмисты: «Аг̃глюмъ своимъ заповђсть $\omega$ тебђ сохранити тА въ всъхъ путехъ твоихъ» (Галят., Ключ 150).

Так само переклав ці лексеми П. Беринда: храню: стерегу (ЛБ 144). Досліджувані тексти засвідчують розмаїття перекладацьких стратегій, застосованих проповідниками. На прикладі Четьї Мінеї Д. Гринчишин, визначив, що основною тенденцією українського перекладу церковнослов'янського тексту було скорочення оригіналу і наближення мови тексту до живої народної мови. Перекладач робив доповнення, вдавався до вільного переказування церковнослов'янського тексту, а також вводив глоси, пояснював незрозумілі слова загальнонародними (ГРинчишин 1995: 253). Ці тенденції знаходять продовження і в досліджуваний період. І. Чепіга зазначала, що у використанні цитат зі Святого Письма виразно проявилася робота письменників над словом. Аналізуючи творчість І. Галятовського, дослідниця вказувала, що, «щедро розсипаючи матеріал конфесійних текстів по своїх творах, І. Галятовський в одних випадках залишає без змін цитату з церковнослов'янського тексту, в інших поряд подає переклад староукраїнською книжною мовою, а деколи 
цитує її в своєму перекладі повністю або частково. Іноді письменник лише переказує зміст цитати, для нього важливо було передати думку, щоб підкріпити те чи інше твердження» (ЧЕпггА 1985: 47-48). І. Чепіга кваліфікувала цитування з одночасним перекладом як різновид глосування: «Одним із типів глос... є переклади староукраїнською мовою наведених у текстах цитат i3 книг... Святого Письма. Такі глоси характерні насамперед для проповідницької літератури» (ЧЕпІгА 1988: 73). Цікавим є використання цитати і перекладу в наведеному далі фрагменті з проповіді 3. Копистенського. Спочатку автор використовує порівняння, джерелом якого є Святе Письмо, потім наводить цитату церковнослов'янською мовою і подає їі переклад:

$W$ короткости ли живота людськогш мовити буду, ано той парђ борзо ищезаючой єстьподобень. Якъ бж(с)т Ап(с)лъ Іакшвъ выражае(т), мовАчи: КаА жизнь ваша, пара оубо естъ, Аже в маль АвлАетсА, потом же ищезаетъ. Аковый же, мовитъ, єстъ животъ вашъ, на кшталтъ пары єсть, котораА скоросА зАвитъ, на тыхъ мъстъ зникаетъ (Коп., Казання 112).

В українському перекладі спостерігаємо заміну лексеми жизнь словотвірним синонімом живот, дієслова ищезаеть на зникаетъ, АвлАетсл - сл завить; а також два способи передачі порівняльного значення: за допомогою лексеми подобень і прийменникового сполучення на кшталт.

У перекладених фрагментах зі Святого Письма широко засвідчено лексеми, засвоєні українською з польської мови. Наприклад, І. Галятовський, цитуючи Еклезіаст, перекладає вислів суєma cyєm, уживаючи полонізм прожность:

ДлА тогФ мовить Екклезїастесъ, же по(д) слинцемъ на свђтђ «суєта суєтствъ и всАческаА суєта», прожность, прожности и все прожность (Галят., Ключ 124).

На використання полонізмів у перекладах звернув увагу В. Сімович і зазначив, що зафіксовані в перекладах запозичення були в активному вжитку тогочасних носіїв мови: «Живучи духовним життям тодішньої української інтелігенції, Галятовський знав і мову тої інтелігенції, й широко нею користувався. У цій мові багато польського впливу, головно в термінології церковній, чи військовій і це й одбилося на перекладах. Галятовський перекладав церк.слов. - відповідними польськими, але ж уживаними серед освічених кляс... Крім цього Галятовський, як і всі тодішні письменники, кохається в польських сполучниках та частицях і правильно їх уживає. Тільки ж багато 3 цих слів поробилися вже тоді були нашими, і живуть і досі в українській мові. Згадаємо такі, що попереходили до польської мови 3 німецької, а опісля запанували і в нас, і досі відомі в цілій Україні. [...] багато з таких і подібних слів, хоч вони явні полонізми, і досі живуть між народом у поодиноких околицях; розуміється, що в XVII ст., певне, вони вживалися дуже широко, бо вплив польський був іще сильніший, тим то їх уже треба вважати за українські, дарма що дісталися вони до нас із польської мови... Письменник старався бути зрозумілим для народа й вибирав для перекладу слова поточної 
укр. тодішньої мови, що їх тоді уживали, не дивлячись на те, звідкіля яке слово взято. Коли мати це на увазі, то тоді «полонізми» в перекладі стануть ясніші, й менше їх буде і тоді можна буде зрозуміти захоплення мовою Галятовського взагалі одного з найкращих знавців ії...» (СІмович 1930: 22-25). Уживання в перекладах полонізмів та запозичень 3 інших мов спостерігаємо в різних авторів. Так, Д. Туптало тлумачить церковнослов'янізми, ужиті в цитатах, полонізмами, напр., вкусите - скоштуйте, изтязовати - бадатися:

Вспомню еще тут и Давида. Той Боголюбецъ, хотячи негды подати людямъ Бога до познанія... мовитъ так: вкусите и видњте, яко благ Господь (Псал. XXXIII). Скоштуйте, мовить и видьте, яко добры Бог (Туптало 5).

Али он въ бесьдах своихъ на Павлова посланія повьдал: «сіе естъ славити Бога еже не изтязовати испытанія». Що жъ то есть не истязовати испытанія? Не бадатися о Бозђ, не дишкуровати (Туптало 11).

Порівняймо переклад у П. Беринди: въкушаю - коштую; истазаю - выпьтую, выљбадую (ЛБ 21, 51).

А. Радивиловський будує проповідь, присвячену Богородиці, розвиваючи думку, втілену в старозавітній цитаті:

Нъст се инаго но до(м) Бжій и си врата нб(с)наА (Рад., Огородок рг̃i).

Ужитий у цитаті церковнослов'янський варіант врата в авторському тексті замінено полонізмом брама (ЕСУМ 1: 244), що активно вживався в українській мові XVII ст. (СУМ 16-17, 3: 49) та зберігся до сучасного періоду (CУM 1:226):

Єсть Брамою нашею Маріа для того же през ню якю през браму входимо до нб̃а (Рад., Огородок $\tilde{\text { ss). }}$

Аналогічні зразки вживань синонімів врата - брама знаходимо і в проповіді І. Галятовського:

Двъ брами, которыєсА на свђтъ знайдують, єдна широкаА брама, котораА до пекла провадить, а таА єсть грђхъ ведлуг словъ Хйыхъ: «ПространнаА врата и широкъ путь въводАй в пагубу». ДругаА брама узкаА, котораА провади(т) до нб̄а, а таА єсть добрыє учынки, ведлугъ словъ Хйыхъ: «УзкаА врата и тьсенъ путь въводАй въ животъ» (Галят., Ключ 223).

В іншому фрагменті церковнослов'янізму сокровище, вжитому в цитаті зі Святого Письма, відповідає слово скарб, запозичене через польське посередництво $з$ давньоверхньонімецької мови (ЕСУМ 5: 265) і яке збереглося в сучасній українській мові (СУМ 9: 252):

И длА тогФ убогїи сутъ богатыми, бо они в(ъ) ср(д)цу своємъ скарбъ дхохоный, цноты и добрыи учынки маютъ, который скарбъ споминаль Хर̃ , мовАчи: «Блгїй

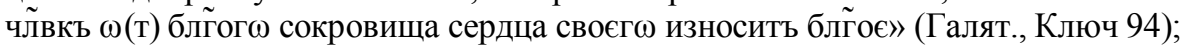

слову милостиня - полонізм ялмужна: 
Пожытокъ и то єст(ъ) ялмужны, которую гды даємо убогимъ, въ памАти своєй бг̃ъ тую ялмужну маєтъ... «Молитва твоА и мл(с)тынА твоА взыйдшша на памАть пре(д) бг̃омъ (Галят., Ключ 89).

Слово ялмужна було відоме носіям української мови і в наступні періоди, його вносить до реєстру словника П. Білецький-Носенко (Біл.-Нос. 413).

Спостерігаємо випадки, коли до спільнослов'янської лексеми, що побутувала і в українській мові, автор добирає іншомовний синонім. Наприклад, слову стьна (ЕСУМ 5: 419-420), ужитому в цитаті, у коментарі відповідає іменник мур «кам'яна або цегляна стіна», запозичений із середньоверхньонімецької мови через польське посередництво (ЕСУМ 3: 535), який, проте, семантично більш виразний і дає змогу точніше передати авторську думку:

Розмаитыми и бг̃ назвалъ пр(о)рка Ієремњю, мовАчи до негш «Дахъ тА десь въ градъ твердъ и въ столпъ желђзный, и въ стђны мЂдАны», - бо на него мнюгїи

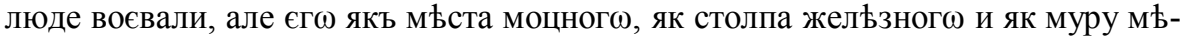
ДАногФ, не могли рушити и преконати (Галят., Ключ 151).

Слово муръ як відповідник реєстровому стьна подає П. Беринда (ЛБ 124).

Найбільш поширеним різновидом перекладацької діяльності були перекази старозавітних та євангельських історій, супроводжувані тлумаченнями і коментарями авторів проповідей. У таких зразках виразно простежуємо специфіку проповідницького твору. Через проповідь священик прагнув вплинути на адресата, на його почуття, щоб переконати в необхідності жити відповідно до норм християнської моралі. Свангельські історії слугували повчальними прикладами, тому проповідники часто творчо підходили до матеріалу зі Святого Письма: вони домислювали сюжети, стилістично увиразнювали текст, могли надавати йому підвищеної емоційної тональності. Тому, крім фіксації рис народної мови, перекладені фрагменти цікаві з погляду літературного опрацювання прецедентного тексту. Наведемо для порівняння фрагменти з відомої притчі про блудного сина. В Острозькій Біблії:

Чл̃къ нђкъи имъ два сега. и рече юнђйшїи єго w(т)цу, w(т)че даждь ми достойную имъниїа и раздъли има имънъе. И не по мнохзъ(х) дне(х) събравъ все мній снъъ(т)иде на страну далече, и ту расточи имънїе свое живы блудно. и иждившу же ему все. Бысть гла(д) крђпокъ на странъ той. И той начатъ лишатися и шед и прильписА єдиному $w($ т) житель тоа страны и посла на села своА пасти свинїА и желаше насытити чрево свое $w($ т) рожецъ яже ядАхусвинъА и никтоже дааше ему (Остр. Бібл. л̈з).

Можемо зіставити кілька варіантів її перекладу - у Пересопницькому євангелії:

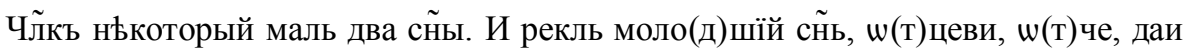
ми достоиноую часть имънъа и розделиль и(м) имънїє. Не по многыхь пакь днєхь меншъй сйь всє забравши и пошль в сторону далекую и там потратиль все свое имънїє, живучи шблудно, а коли южь все утратиль, стался голодъ ве- 
ликый въ оной то сторонђ. А шнъ почаль недостатокь тръпьти. И шодши присталь къ єдиному чллку, живучому в шномь то мъсть, который жє то послаль єго до села свого, абы пасль свинъ. А он юж бы быль рад наситити чрево свое от рожець, або млутомь, або отрубями, которыи єдалы свинь (ПЄ 287);

\section{в Учительному євангелії, перекладеному М. Смотрицьким:}

Чл̃вкъ нъкоторый мълъ два сыны. Й реклъ моло(д)ший з ныхъ дай ми часть маетности, которая на мене приходить. И роздълиль межи них

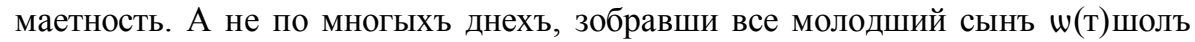
в далекую сторону и там роспорошиль маетность свою, живучи вшетечне. А кгды все потратилъ стался голодъ великий в сторонђ той, а оному почало недоставати. И шедши прысталъ до одного з обывателевъ стороны той, который его послаль на село свое пасти свыній. И жадаль накормити черево свое рожками, которыхъ свынь єлы (См., УС 35).

По-іншому постає ця притча з уст А. Радивиловського: автор переказує iї в кількох проповідях. У його розповіді узагальнена лексема чоловік замінена словом господар, 3 яким в українській свідомості пов'язано усталені асоціації - воно є одним з мовних знаків української етнокультури (ЖАйвоРонок 2006: 149). Проповідник опускає окремі деталі, водночас додає свої, доповнює розповідь власними міркуваннями, акцентує на тому, які саме вияви поведінки є аморальними. Свангельська історія постає перед слухачем і читачем, пройшовши крізь свідомість, включаючи й мовну, автора:

Пишетъ Лука ст̃й ш єдно(м) Г(с)подару, который мълъ двох сӥшвъ. Молодшїй СЫН, ХОТАЧИ ВОЛНЫМъ бЫТИ, ХОТАЧИ ТаКъ ЖИТИ, ЯКъ СаМъ ХОТЪЛЪ, За ТАЖКУЮ рђчъ себе маючи, же єму отець єгш росказуетъ, же ему сваволь не допущаетъ, же $\epsilon \Gamma w$ до боАзни Б̈жой заправуетъ. Выдыраетса 3 шпеки и по(д)данства w(т)ца своегш мовАчи: Даждъ ми достойную часть имЪнъА. Учинилъ такъ отець, вЫпустылъ єго з шпеки своеи, з которои он вышедши удалсА в далекую краину, и

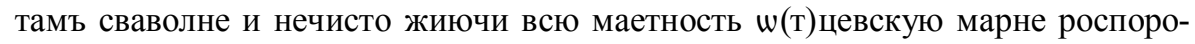
шилъ, єдно пропиль, другое на вшетечницы шбернулъ, чрезъ чтш до такои нендзы пришо(л) иж у єдиного житель та(м) тои стороны свинъ пасти мусњлъ и то Асти, что ядаху свинїа (Рад., Вінець рла зв.).

Наведені фрагменти, подібними до яких пронизано проповідницькі твори, демонструють, що ресурс української мови дозволяв реалізувати переклад у кількох варіантах: так, црк.-сл. живы блудно відповідають словосполучення живучи облудно (ПЄ), живучи вшетечне (УЄ), в обох випадках використано дієприслівники теперішнього часу на -чи. У переказі А. Радивиловський уживає форму інфінітива жити й увиразнює значення, добираючи два відповідники до прислівника - лексеми свавольне й нечисто. Церковнослов'янське страну перекладено - сторону (ПЄ, УЄ); в А. Радивиловського словами краину, сторону. П. Беринда до слова страна добирає відповідники повъm, cmoрона, краина (ЛБ 122). На слові сторона як виразному народнорозмовному елементі акцентує У. Сдлінська, аналізуючи лексичний склад Учительного 
Євангелія, і зазначає, що воно було дуже поширеним у пам'ятках української мови незалежно від жанру (СдлгнськА 1961: 55). Церковнослов'янське расточи замінено дієсловами потратиль (ПЄ), роспорошиль (УС), А. Радивиловський - роспорошиль. У П. Беринди: растрачаю: роспорошую (ЛБ 107); црк.-сл. имъние - имънїє (ПЄ); маетность (УЄ), А. Радивиловський -маетность; П. Беринда - богатство, маетность (ЛБ 48). В іншому випадку до слова имънїє дібрано як відповідник словосполучення добра $w(m)$ чевскогw, вказано на конкретні вияви «блудного життя»:

...добра єго марне роспорошаетъ на пїАтики, на танцы, на музыки, на вшетечницы (Рад., Вінець роч).

Переказування проповідник може поєднувати з цитуванням оригіналу, особливо коли це репліки, і перед ними або після них подає широкі коментарі, домислює сюжет, наповнює його новими деталями. Саме в таких випадках цитата і авторська розповідь тісно переплітаються, лексичні елементи церковнослов'янської, української, польської мов постають єдиним потоком. У наведеному уривку з пам'ятки звернемо увагу на епітетний ряд, яким змальовано сина, що повернувся після довгих поневірянь:

Же сын марнотравный, якш повернулъ до ш(т)ца своего, шбачивши єго штец высхлого, избльднълого, обдертого, нъчого про(ч) торбы пастырской немаючого, босого, заволает до слуг свои(х): Изнесьте шдежду первую и шблецьте єго (Рад., Вінець ре чз).

У ряду епітетів спостерігаємо дієприкметникові форми на -л(ий). Тенденція до творення названих дієприкметникових форм була успадкована і новою літературною мовою (РусАнІвський 1988: 203), досі в ній уживається лексема висхлий (СУМ 1: 506). Негативно оцінюючи поведінку блудного сина, автор послуговується семантично містким епітетом марнотравний. Однокореневі до цього атрибутива лексеми засвідчено в «Лексиконі» П. Беринди в таких синонімічних рядах: блудъ, вшетеченство «розпуста», марнотравство, збьток (ЛБ 10); блудно, вшетечне, марнотравне, роспустнш (ЛБ 11). У «Матеріалах» Є. Тимченка словосполучення марнотравный сын подано як стійке із вказівкою на польське походження прикметника (Тимч., Матер. 1: 421). В українській мові наступних століть уживалися також дієслово марнотравити, іменники марнотравство, марнотрав, марнотравство (Біл.-Нос. 220).

Творчим вимислом А. Радивиловського є переказ сюжету з Свангелія від Луки про заблудлу вівцю. Наведемо цей епізод з Острозької Біблії:

Кїи чл̃къш(т) васъ имы сто овець и погубль єденуш(т) них, не шставитъ ли де-

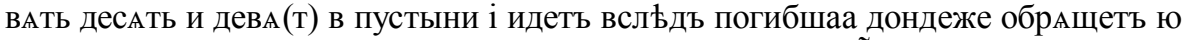
и обрђтъ възлагаетъ на рамъ свои радуАсА (Остр. Бібл. 3, л̈з).

На основі цієї притчі автор словесно вимальовує проникливий образок, вводить епітети, використовує повтори, демонструючи виразовий потенціал української мови: 
Пастыръ той ходылъ по высокихъ горахъ и прыкрыхъ, по болотныхъ долинахъ, мусьлъсА драпати, по шстрыхъ хростинахъ, мусьл блукати по страшныхъ льсахъ, мусьл гладъ и жажду великую далеко w(т) домуш(т)шедши терпьти, мусьлса не раз добре запотити, а в том всемъ не усталъ, аж овечку погибшую шбрьте. ...шбрьтши ю зхорьлую ужалися над нею и не женеть єи пре(д) собою, але берет ю на рамена, нъчогш того не уважаючи, же в шуканю еи барзо змордовал, же голодом и прагненємъ барзо стратилъ, несете ю з великою радостъю до овчарнь своеи (Рад., Вінець ра̃в зв.).

Звернемо увагу на атрибутив прикрий, який уживався довгий час в українській мові зі значенням «крутий» (Біл.-Нос. 299, СУМ 7: 649). Коментуючи вчинок доброго пастиря, проповідник додає деталей:

...овечку згубывши, такъ еи пильно и з великою працею шукаетъ (Рад., Вінець ра̃в 3в.).

Зразки творчого опрацювання євангельських сюжетів знаходимо і в проповідях Д. Туптала. В одній з них проповідник переповідає фрагмент Євангелія від Матвія (гл. 21), у якому йдеться про те, як Ісус вигнав торговців із храму. В Острозькій Біблії цей епізод передано в такій редакції:

И вниде в црорквь бӝїю, изгна всА продающаА и купующаА в цгіркви, и трапезы тръжнїкомъ испроверъже, и сьдалищА продающаА голубы (Остр. Бібл. айві),

у Пересопницькому Свангелії перекладено:

Вшол І̃с до храму бжієєо и выгна(л) всА продающаа и купующаа в црекви. Надто и столы трьговцо(м) попереверталь и столцђ ты(х) которыи продавали голубы выметаль (ПЄ 178).

Використовуючи цей сюжет у промові, Д. Туптало деталізує його. У власний переказ включає лексему торг і подає до неї глосу - слово ярмарок, яке увійшло в народну мову з німецької, можливо, через польське посередництво (ЕСУМ 6: 552). Крім згаданих євангелістом голубів, у версії Д. Туптала торговці привели на продаж ще й овець та волів, перебували в храмі не тільки торжники, а й пьняжники «міняйли» $з$ грошима:

Вшолъ раз Христос до церкви... видить ано тамъ торгъ, чи ярмарок, обрђте в церквђ продающіа овца, и волы и голоби, и пъняжники сьдящия, що то гроши мъняють (Туптало 51).

Колоритно описує проповідник, як саме було вигнано торговців: Ісус бив їх палицею - бичем, і вони змушені були тікати. Оживляють зображуване лексеми на позначення частин тіла - іменники зашийок, плечі, прислівник - врозтіч, дієприслівник - попихаючи, особливої експресії розповіді надає фразеологізм набратися пуду:

Возмет бычъ, тнет одного и другого по зашейку, по плечемъ, вси вростичъ, один другого попихаючи, досталось там не одному фарисею, и садукей там набрався пуду, и шкоды стало не мало торжныком разсыпа пънязђ (Туптало 51). 
У сучасній українській мові вживається стійке словосполучення гнати в зашийок «грубо гнати кого-небудь» (СУМ 3: 414), а також фраземи давати (дати) пуду; наганяти (нагнати) пуду - лякати, страшити кого-небудь; набратися (зазнати) пуду - перелякатися (СУМ 8: 384).

У перекладах і переказах, крім виразних лексичних і морфологічних рис української мови, спостерігаємо синтаксичні. Наприклад, в українській мові простежувалася тенденція до розвитку конструкції з прийменником до + род. відм.; $з$ прийменником з $a+$ знах. відмінок, що вказує на те, ким вважають, сприймають визнають предмет чи особу (ГРищЕнко та ін. 1983: 215, 174, 184). Поширеними вони були в Пересопницькому Свангелії (ЧЕПггА 2001: 47, 48). Виявлено такі конструкції і в досліджуваних текстах: на позначення місця дії: вшоль до ичеркви; об'єкта, на який спрямована дія: ...до такои нендзы пришо $(л)$; до болзни божой заправуетъ; адресата мовлення: заволает до слуг; чим є предмет: за тажкую рбчъ себе маючи. Характерною рисою української мови є вживання дієслівного складеного присудка з дієслівною зв'язкою мусити (ГРищЕнко та ін. 1983: 38), що документують і досліджувані тексти: свинъ пасти мусъль; мусъл блукати по страшныхъ льсахъ. Риси живої української мови знаходять вияв у використанні сполучників чи, але: торгъ, чи ярмарок; не женет..., але берет... на рамена. Саме на ці службові слова як на виразну живомовну ознаку творів І. Галятовського вказує К. Симонова (див. Симонова 2011: 179, 181).

Наведений матеріал дає змогу констатувати, що українські письменники XVII ст. продовжували давню традицію перекладу та творчого опрацювання Святого Письма, а отже, ця ідея остаточно утвердилася в мовній свідомості тогочасних носіїв мови. Барокові проповідники змінювали стиль викладу прецедентного тексту, надавали емоційної тональності, шляхом використання художніх засобів та риторичних прийомів робили його естетично вартіснішим. Такий спосіб перекладу був зумовлений настановою проповіді: вплинути на адресата, на його емоції, почуття, переконати в необхідності жити відповідно до норм християнської моралі.

\section{Джерела}

Біл.-Нос. = БІЛЕцьКИй-НОСеНко П. П. Словник украӥнської мови. Підг. до вид. В. В. Німчука. Київ: «Наукова думка», 1966.

Галят., Ключ = ГАлятовський І. Ключ розуміння. Підг. до вид. І. П. Чепіги. Київ: «Наукова думка», 1985. 53-211.

ЕСУМ = МЕЛЬничук О. С. (ред.) Етимологічний словник української мови. Т. 1-6. Київ: «Наукова думка», 1982-2012.

ЛБ = Лексикон словенороський Памви Беринди. Підг. тексту і вступ. ст. В. В. Німчука. Київ: «Видавництво АН УРСР», 1961.

Мог., Хрест = МогилА П. Хрест Спасителя і кожної людини. В кн.: Тітов Хв. Матеріяли для історї книжної справи на Вкраїні в XVI-XVIII вв. Всезбірка передмов до українських стародруків. Київ, 1924. 271-290. 
Остр. Бібл. = Библіа сиріч книгы Ветхаго и Новаго Завъта по языку словенску. Острог: Друкарня К. К. Острозького, друкар Іван Федоров, 1581.

ПЄ = Пересопницьке Євангеліє. 1556-1561. Дослідження. Транслітерований текст. Словопокажчик. Вид. підг. І. П. Чепіга. Київ, 2001.

Рад., Вінець = РАдивиловСьКий А. Вънецъ Хйъ. Київ, 1688.

Рад., Огородок = РАдивиловский А. Огородокъ Марїи Бйыл. Київ, 1676.

См., УЄ = The Jevanhelije učytelnoje of Meletij Smotryc'kyj. (Harvard Library of Early Ukrainian Literature.) Vol. 2. Cambridge, Mass., 1987.

СУМ = БІлодІд І. К. (ред.) Словник української мови. Т. 1-11. Київ: «Наукова думка», 1970-1980.

СУМ 16-17 = Словник украӥнської мови XVI - першої половини XVII cm. Вип. 1-16. Львів: «Інститут українознавства ім. І. Крип’якевича НАНУ», 1994-2013.

Тимч., Матер. = Тимченко Є. Матеріали до словника писемної та книжної української мови XV-XVIII cm. Кн. 1-2. Відп. ред. В. В. Німчук та ін. Київ-Нью-Йорк: «Видавництво Інституту української мови НАНУ», 2002-2003.

Туптало = Титовъ Ан. Проповъди святителя Димитрія, митрополита Ростовскаго, на украинскомъ наръчіи. Москва, 1909.

\section{Література}

ГНАТЮК $2010=$ ГНАТЮК Л. П. Мовний феномен Григорія Сковороди в контексті староукраїнської книжної традииї. Київ: ВПЦ «Київський університет», 2010.

Гринчишин 1995 = Гринчишин Д. Четья 1489 року - видатна конфесійна пам'ятка української мови. В кн.: Записки Наукового товариства ім. Т. Шевченка. Праці філологічної секиії. Т. 229. Львів, 1995. 251-276.

ГрищЕнко та ін. 1983 = ГРищЕнко А. П. та ін. (ред.) Історія української мови. Синтаксис. Київ: «Наукова думка», 1983.

Дидик-МЕуш 2008 = Дидик-МЕуш Г. Закарпатські говіркові риси в мовній тканині неканонічного євангельського тексту XVI ст. В кн.: Сучасні проблеми мовознавства та літературознавства. Украӥнська діалектна лексика як об'єкт словникарства та лінгвогеографії. Вип. 12. Ужгород, 2008. 131-133.

ДоБосЕВич 2007 = ДоБосевич У. Суспільний статус і престиж української мови на зламі XVI-XVII ст. В кн.: Матеріали VI Міжнародного конгресу украӥністів. Мовознавство. Кн. 5. Київ, 2007. 278-288.

ДоБОСЕВич 2013 = ДоБОСЕвич У. У пошуках пожитку для душі: порівняльні конструкції в «Духовних бесьдах» 1627 року. В кн.: Мовні обрії. Відп. ред. О. Сімович. Львів: «Інститут українознавства ім. І. Крип'якевича НАНУ», 2013. 60-75.

СРмОЛЕНко 1989 = СРмОЛЕНко С. Я. (ред.) Жанри і стилі в історії украӥнської літературної мови. Київ: «Наукова думка», 1989.

ЖАЙВОРОНОК 2006 = ЖАЙВОРОНОК В. В. Знаки украӥнської етнокультури. Словникдовідник. Київ: «Довіра», 2006.

ЗолТАН 2006 = ЗолтАН А. Предисловие. В кн.: ЗолТАН А. (ред.) Няговские поучения. Факсимильное воспроизведение текста по изданию А. Л. Петрова с вводной статьей Л. Дэже. Nyíregyháza, 2006. IX-XI.

Нгмчук 2001a = НІмчук В. Свсевієве Свангеліє 1283 р. як пам'ятка української мови. В кн.: Нгмчук В. (ред.) Свсевієве Свангеліє. Київ: «Київський славістичний університет», 2001. 3-38. 
НІмчук 2001 b = НІмчук В. Християнство й українська мова. Українська мова 2001/1: 11-30.

НІмчук 2013 = НІмчук В. Переднє слово. В кн.: Нгмчук В., ПуряєвА Н. Украӥнський «Отче наш». Хрестоматія перекладів. Київ: «Грані-Т», 2013. 7-12.

ОГІєнко 1930 = ОгІєнко І. Украӥнська літературна мова XVI cm. і украӥнський Крехівський апостол 1560 р. Варшава: «Друкарня синодальня», 1930.

Ослнчук 2012 = Ослнчук Ю. Живомовні риси в Добриловому Свангелії 1164 року. В кн.: НІмчук В. (ред.) Добрилове Свангеліє 1164 року. Львів: «Інститут українознавства ім. І. Крип'якевича НАНУ», 2012. 11-35.

ПЕТРОВ $1914=$ ПЕтРОВ А. Л. Памятники иерковно-религиозной жизни угроруссов XVIXVII вв. I. Поучения на Евангелие по Няговскому списку 1758 г. II. Иерея Михаила «Оброна верному члвку»: Teксты. (Материалы для истории Угорской Руси 7.) Петроград: «Типография Академии наук», 1914.

РАХІВськИй 1919 = РАХІВСький О. Виімки из угорсько-руського письменства XVIIXVIII. вв. Budapest: Накладом Русько-краинського республичного совђту, 1919.

РуСАнІВСькИй 1988 = РуСАнІВСьКИй В. М. Структура лексичної $і$ граматичної семантики. Київ: «Наукова думка», 1988.

Симонова 2011 = СимоновА К. Співвідношення книжних і народнорозмовних часток у творах І. Галятовського. В кн.: У силовому полі мови. Пам'яті Інни Петрівни Чепіги. Київ: «КММ», 2011. 176-184.

СІмович 1930 = СІмович В. Спроби перекладів Св. Письма у творах Й. Галятовського. В кн.: Ювілейний збірник на пошану акад. Кирила Студинського. Ч. 1. Праиі філологічні. Записки Наукового товариства імени Шевченка. Т. 99. Львів, 1930. 51-80.

Толстой 1963 = Толстой Н. И. Взаимоотношение локальных типов древнеславянского языка позднего периода. В кн.: Славянское языкознание. Москва: «Издательство АН СССР», 1963. 230-271.

ЧЕПІГА 1985 = ЧЕПІГА І. П. «Ключ розуміння» Іоаникія Галятовського - видатна пам'ятка української мови XVII ст. В кн.: ГАлятовський І. Ключ розуміння. Підг. до видання І. П. Чепіга. Київ: «Наукова думка», 1985. 5-51.

ЧЕПІГА 1988 = ЧЕПІГА І. П. Глосування як форма лексикографічної роботи в творах Іоаникія Галятовського. В кн.: Роль Києво-Могилянської академії в культурному єднанні слов'янських народів. Київ: «Наукова думка», 1988. 70-75.

ЧЕПІГА 1995 = ЧЕПІГА І. П. Взаємодія української і церковнослов'янської мов XVI століття (на матеріалах перекладів Свангелія). В кн.: Записки Наукового товариства ім. Т. Шевченка. Праці філологічної секції. Т. 229. Львів, 1995. 277-288.

ЧЕПІГА 2001 = ЧЕПІГА І. П. Пересопницьке Євангеліє - унікальна пам'ятка української мови. В кн.: Пересопницьке Свангеліє. 1556-1561. Дослідження. Транслітерований текст. Словопокажчик. Вид. підг. І. П. Чепіга. Київ, 2001. 13-54.

ЧуБА $2000=$ ЧуБА Г. Мовні засоби впливу на слухача в українських учительних євангеліях кінця XVI ст. В кн.: Християнство й украӥнська мова. Матеріали наукової конференції. Львів: «Видавництво Львівської богословської академії», 2000. $449-461$.

ЧуБА 2011 = ЧуБА Г. Рукописні учительні Євангелія в історії українського проповідництва. В кн.: ЧуьА Г. Українські рукописні учительні Євангелія. Дослідження. Каталог. Описи. Київ-Львів: «Свічадо», 2011. 5-28. 